\title{
Vertical transmission in chikungunya infection
}

\section{P Senanayake ${ }^{1}$, S M Senanayake ${ }^{1}$, K K Vidanage ${ }^{1}$, S Gunasena ${ }^{2}$, S P Lamabadusuriya ${ }^{1}$}

(Index words: chikungunya, vertical transmission)

\section{Abstract}

We report the pregnancy outcome and clinical and laboratory findings in infants born to women with chikungunya infection during pregnancy. There was evidence of vertical transmission and poor pregnancy outcome in some cases.

\section{Introduction}

In the outbreak of chikungunya viral fever in Sri Lanka in 2006-2007, densely populated areas in the city of Colombo were worst affected. Although chikungunya is now ranked among the most quoted viruses in the literature, few reports document maternal to fetal transmission $[1,2]$.

Chikungunya in pregnancy was encountered in Colombo, and we report pregnancy outcome and clinical and laboratory findings in infants born to a cohort of pregnant women with serologically proven chikungunya infection.

\section{Methods}

This prospective, descriptive study included 48 pregnant women attending maternity clinics of Colombo Municipal Council between 1 April 2007 and 31 October 2007 with confirmed chikungunya infection, and 2 women whose neonates were admitted to the Professorial ward at Lady Ridgeway Children's Hospital with perinatal chikungunya infection during this period.

Case definition of the National Institute of Virology, Pune, India, and serological confirmation by testing for chikungunya and dengue specific antibodies after informed consent, identified the study population. Ethical clearance was obtained from the Ethics Committee of the Faculty of Medicine, University of Colombo. Those with concomitant dengue antibodies were excluded.

Timing of infection and distance to delivery, obstetric complications and neonatal examination findings were recorded. Neonatal details noted were birth weight (BW), gestational age, physical features and cardiac assessment.

${ }^{1}$ Department of Paediatrics, Faculty of Medicine, University of Colombo, Sri Lanka and ${ }^{2}$ Medical Research Institute, Colombo, Sri Lanka.

Correspondence: MPS, e-mail <paed_colombo@yahoo.com>. Received 1 September 2008 and accepted 10 January 2009. Competing interests: none declared. 
Cord or peripheral blood from neonates was tested for presence of chikungunya specific IgM antibodies.

\section{Results}

Fifty serologically chikungunya positive and dengue negative pregnant women [Mean (SD) age: 28 (4.8) years] were included in the study. Haemagglutination inhibition assay (HAI) on single samples of maternal blood collected during the convalescent phase found definitive exposure (HAI titre > 160) in 40 women and possible exposure (HAI titre 80 ) in 10 . Chikungunya IgM antibodies were positive in seven newborns. The timing of febrile illness was during first, second and third trimesters of pregnancy in 21 (42\%), $21(42 \%)$, and $7(14 \%)$ respectively and in the immediate post partum period in $1(2 \%)$.
Two pregnancies ended in abortion and one in an intrauterine death. One of the abortions occurred while the mother had acute symptoms of chikungunya at 17 weeks of amenorrhoea. The intrauterine death was at 33 weeks after a first trimester infection, and the fetus weighed $1.6 \mathrm{~kg}$ at postmortem and showed multiple congenital abnormalities of the heart and limbs. The three aborted fetuses were not virologically studied. Six women were lost to follow up. Two pregnancies ended in preterm deliveries while 39 proceeded to term with no obstetric complications. One preterm delivery was during the acute, febrile phase of maternal chikungunya.

A total of 4 women ( $8 \%$ ) who had live born babies were clinically viraemic at the time of delivery. All others had a period of at least 4 weeks between the febrile phase and delivery.

\section{Table 1. Timing of infection, pregnancy and neonatal outcome, and serological findings in $\mathbf{5 0}$ pregnancies with chikungunya infection}

\begin{tabular}{|c|c|c|c|c|}
\hline Timing of infection & First trimester & Second trimester & Third trimester & $\begin{array}{l}\text { Post partum } \\
\text { period }\end{array}$ \\
\hline $\begin{array}{l}\text { No. of pregnancies } \\
\qquad \mathrm{n}=50\end{array}$ & $21(42 \%)$ & $21(42 \%)$ & $7(14 \%)$ & $1(2 \%)$ \\
\hline \multicolumn{5}{|l|}{$\begin{array}{c}\text { Maternal serology } \\
n=50\end{array}$} \\
\hline $\mathrm{HAI}>160$ & 16 & 17 & 7 & 0 \\
\hline $\mathrm{HAI}>80$ & 5 & 5 & 0 & 1 \\
\hline \multirow{2}{*}{$\begin{array}{l}\text { Pregnancy outcome } \\
\qquad n=50\end{array}$} & $\begin{array}{l}\text { Abortion } \\
\text { IUD at } 33 \text { wks }\end{array}$ & Abortion & Preterm deliveries (2) & \multirow[b]{2}{*}{ Term delivery (1) } \\
\hline & Term deliveries & Term deliveries (17) & Term deliveries (5) & \\
\hline \multirow{9}{*}{$\begin{array}{l}\text { Neonatal outcome } \\
\qquad \mathrm{n}=41\end{array}$} & Abnormalities & Abnormalities & Abnormalities & Abnormalities \\
\hline & \multirow{5}{*}{$\begin{array}{l}\text { PDA + Stridor (1) } \\
\text { ASD + pigmentation (1) } \\
\text { ASD (1) } \\
\text { PFO (2) } \\
\text { IUGR (1) }\end{array}$} & \multirow[t]{5}{*}{ None } & Meningoencephalitis (1) & \multirow{5}{*}{$\begin{array}{l}\text { Fever, } \\
\text { myocarditis, }+ \\
\text { generalized } \\
\text { pigmentation }(1)\end{array}$} \\
\hline & & & Preterm + Resp. & \\
\hline & & & distress (1) & \\
\hline & & & Failure to thrive + & \\
\hline & & & splenomegaly (1) & \\
\hline & \multirow{3}{*}{$\begin{array}{l}\text { Healthy newborns } \\
\text { (10) } \\
\text { (pigmentation 4) }\end{array}$} & Healthy newborns & Healthy newborns & \multirow{3}{*}{$\begin{array}{l}\text { Healthy newborns } \\
\text { (0) }\end{array}$} \\
\hline & & (17) & (3) & \\
\hline & & (pigmentation 3 ) & (pigmentation 2) & \\
\hline \multirow{3}{*}{$\begin{array}{l}\text { Newborn serology } \\
\qquad \begin{array}{c}(\operatorname{IgM}) \\
\mathrm{n}=32\end{array}\end{array}$} & \multirow{3}{*}{$\begin{array}{l}\text { Positive } 2 \\
\text { Negative } 8\end{array}$} & Positive 1 & Positive 3 & \multirow{3}{*}{$\begin{array}{l}\text { Positive } 1 \\
\text { Negative } 0\end{array}$} \\
\hline & & Negative 7 & Negative 10 & \\
\hline & & & & \\
\hline
\end{tabular}


Table 2. Clinical and serological details of infants born to mothers during viraemic phase $(n=4)$

\begin{tabular}{|c|c|c|c|c|c|c|c|}
\hline $\begin{array}{l}\text { Patient } \\
\quad \text { No }\end{array}$ & $\begin{array}{c}\text { Timing } \\
\text { of infection } \\
\text { (Trimester) }\end{array}$ & $\begin{array}{c}\text { Maternal } \\
\text { serology } \\
\text { (HAI titre) }\end{array}$ & $\begin{array}{c}\text { Distance } \\
\text { to delivery } \\
\text { (wks / days) }\end{array}$ & $\begin{array}{l}B W \\
(\mathrm{~kg})\end{array}$ & $\begin{array}{c}\text { Gestational } \\
\text { age } \\
\text { (weeks) }\end{array}$ & $\begin{array}{l}\text { Clinical } \\
\text { features }\end{array}$ & $\begin{array}{c}\text { Newborn } \\
\text { Serology } \\
\text { (IgM) }\end{array}$ \\
\hline 17 & $3 \mathrm{rd}$ & 640 & +4 days & 1.44 & $\begin{array}{l}\text { Preterm } \\
(30 \text { weeks })\end{array}$ & $\begin{array}{l}\text { Severe } \\
\text { RDS }+ \\
\text { Pigmentation }\end{array}$ & negative \\
\hline 36 & $3 \mathrm{rd}$ & 320 & +5 days & 2.75 & term & $\begin{array}{l}\text { Seizures } \\
\text { Microcephaly, } \\
\text { dev delay }\end{array}$ & $\begin{array}{l}\text { Sample } \\
\text { haemolysed }\end{array}$ \\
\hline 49 & $3 \mathrm{rd}$ & 160 & +5 days & 2.6 & term & $\begin{array}{l}\text { Loss of weight }+ \\
\text { splenomegaly }\end{array}$ & negative \\
\hline 50 & $3 \mathrm{rd}$ & 160 & -1 day & 2.8 & term & $\begin{array}{l}\text { Myocarditis, } \\
\text { heart failure, } \\
\text { generalised } \\
\text { pigmentation }\end{array}$ & positive \\
\hline
\end{tabular}

The 36 infants born at term, in whom maternal infection had occurred distant to date of delivery, had a mean (SD) birth weight of $2.93(0.5) \mathrm{kg}$ and were apparently healthy. Five had cardiac murmurs and echocardiography confirmed atrial septal defect (ASD) in 2, patent ductus arteriosus in 1 and persistent foramen ovale (PFO) in 2. The infant with patent ductus arteriosus (PDA) also had congenital stridor. Eleven healthy infants had localised skin pigmentation which were well demarcated and mostly on the lower limbs. In 10 infants the pigmentation was bilateral and symmetrical over joint line of the knees which were neither swollen nor painful. These infants thrived and developed normally during the first 6 months and the pigmentation disap-peared by 6 to 7 months. Three of the eleven infants with pigmentation tested positive for chikungunya IgM antibodies, six were negative and two were not tested due to haemolysed samples. Timing of infection, maternal and newborn findings, and serology are shown in Table 1. All 4 infants delivered during the viraemic stage of maternal infection had serious illness needing hospitalisation (Table 2).

\section{Case 1}

There was severe respiratory distress due to extreme prematurity ( $30 \mathrm{wks}, \mathrm{BW} 1.4 \mathrm{~kg}$ ), but the baby recovered with ventilatory support. He had no pigmentation and was negative for chikungunya antibodies.

\section{Case 2}

The baby was a full term delivery with a BW of 2.75 $\mathrm{kg}$. He developed neonatal seizures from day 2. Blood sugar, electrolytes and cerebrospinal fluid (CSF) were normal, but was managed as meningoencephalitis. CSF was not tested for chikungunya virus. The blood sample obtained for chikungunya antibodies was haemolysed. He has residual developmental delay and microcephaly.

\section{Case 3}

This neonate was investigated for loss of weight during the first month. There was splenomegaly of $1 \mathrm{~cm}$ and pigmentation on lower limbs. Chikungunya IgM antibody was negative at seven weeks.

\section{Case 4}

The infant was febrile and lethargic on day 2. Blood cultures were negative. Generalized macular brown pigmentation and heart failure developed. A diagnosis of myocarditis was made with electrocardiographic changes and a reduced ejection fraction. Chikungunya IgM antibody was positive. A full recovery followed treatment for heart failure, and he has remained well with normal growth and development. His mother developed fever hours after delivery and had joint involvement and other clinical features of chikungunya. 


\section{Discussion}

The diagnosis of chikungunya fever was made in pregnant mothers on suggestive clinical features and high specific antibody titres during an outbreak of fever in the city of Colombo. A single convalescent sample was considered adequate for serological diagnosis because Sri Lanka had not reported chikungunya fever since a distant outbreak in 1965 [3]. All women in our study were less than 42 years of age, denied previous infection, and tested negative for dengue, an endemic virus causing a similar febrile illness.

Based on positive serology in neonates, we found vertical transmission to have occurred in all three trimesters. Six of the serologically positive infants were apparently well and infection appeared relatively harmless. This included those infected in the first trimester. Our study did not investigate an abortifacient role of the virus, although we observed one abortion that occurred during the acute febrile phase of the illness in the mother. When time distance to delivery was 4 or more weeks after infection infants seemed unaffected, but serious consequences were seen in all infants whose mothers were viraemic at delivery. Meningoencephalitis has been previously reported [4], but we were unable to establish the incriminating virus due to a technical error. The infant of one woman who developed clinical illness in the immediate postpartum period and was possibly viraemic at delivery had serologically proven perinatal chikungunya. Myocarditis and generalized pigmentation were the predominant clinical features in this infant who was seriously ill for over a week [5]. The skin lesions we noticed were in apparently healthy infants as well as in one sick neonate. Although pigmentation has been reported previously, a hereto unreported distribution of pigmentation was present in our series, and we recommend further study to establish a causative link. Joint involvement is a characteristic symptom in chikungunya viral fever and whether the pigmentation over joints is of significance during intrauterine infection needs closer scrutiny.

Outbreaks of chikungunya in Africa and South Asia in 2005-2006 [6,7] were followed by reports of over a 100 cases due to local transmission in north-east Italy by June 2007 [8]. Vertical transmission of the virus requires further attention because this infection now threatens to become a widespread public health problem.

\section{Acknowledgements}

We thank Dr. Pradeep Kariyawasam, Chief Medical Officer of Health and medical officers, nurses and midwives of the Maternity Clinics of the Colombo Municipal Council for assistance.

\section{References}

1. Lenglet $Y$, Barau G, Robillard PY, Randrianaibo H, Michault A, Bouveret A, et al. Chikungunya infection in pregnancy: evidence for intrauterine infection in pregnant women and vertical transmission in the parturient. Survey of the Reunion Island outbreak. Journal of Gyanaecological and Obstetric Biological Reproduction 2006; 35: 578-83.

2. Ramful D, Carbonnier M, Pasquet M, Bouhmani B, Ghazouani J, Noormahomed T, Beullier G, Attali T, Samperiz S, Fourmaintraux A, Alessandri JL. Mother-to-child transmission of Chikungunya virus infection. The Paediatric Infectious Diseases Journal 2007; 26: 811-5.

3. Munasinghe DR, Amarasekera PJ, Fernando CFO. An epidemic of dengue-like fever in Ceylon (Chikungunya) - A clinical and haematological study. Ceylon Medical Journal 1966; 11: 129-42.

4. Robillard PY, Boumahni B, Gerardin P, Michault A, Fourmaintraux A, Schuffenecker I, Carbonnier M, Djemili S, Choker G, Roge-Wolter M, Barau G. Vertical maternal fetal transmission of the chikungunya virus. Ten cases among 84 pregnant women. Presse Medicine 2006; 35: 785-8.

5. Maiti CR, Mukherjee AK, Bose B, Saha GL. Myopericarditis following chikungunya infection. Journal of the Indian Medical Association 1978; 70: 256-8.

6. Mourya DT, Mishra AC, 2006. Chikungunya re-emergence: Possible mechanisms. Available from: http://www. thelancet.com

7. Parola D, de Lamballerie X, Jourdan J, Rovery C, Vaillant V, Minodier P, Brouqui P, Flahault A, Raoult D, Charrel RN, 2005. Novel chikungunya virus variant in travelers returning from Indian Ocean islands. Emerging Infectious Disease 2006; 12: $1493-9$

8. Angelini R, Finarelli A C, Angelini P, Po C, Petropulacos K, et al. An outbreak of chikungunya fever in the province of Ravenna, Italy. European Surveillance 2007 ; 12: E070906.1. 